\title{
Isolation of Pathogenic Bacteria from Poultry Wastages at Chennai Suburban
}

\author{
Mathan Periasamy ${ }^{1, *}$, Patricia Trueman ${ }^{1}$, Aswin Adhimani $^{1}$, Gunaseelan \\ Sathaiah $^{1}$, Karthick Ravichandran ${ }^{1}$, Mayur Kedare ${ }^{1}$, Narayanan Manoharan ${ }^{1}$ \\ ${ }^{1}$ Department of Biotechnology, Sree Sastha Institute of Engineering and Technology, Chembarambakkam,
} Chennai-600 123, India.

\begin{abstract}
India is one of the largest broiler producers in the world. Huge quantities of poultry wastages are generated and dumping of these wastes causes several environmental pollution problems. One of the serious problems is, it also serves as a nutritional source for the growth of several pathogenic bacteria and thereby causes disease outbreaks. This work addresses this environmental issue through enumeration, isolation and identification of microorganisms from the dumping sites of poultry wastages. Samples were collected from five different regions and bacterial isolates obtained were then purified into pure culture and identified based on their morphological, cultural and biochemical tests by standard microbiological procedures. The isolated pathogenic organisms were Vibrio choleare, Vibrio parahaemolyticus, Salmonella typhi, Shigella dysenteriae, Shigella sonnei and Klebsiella pneumonia. The colonization of pathogenic bacteria in poultry waste dumping sites is highly hazardous to the environment and these poultry wastages need a prompt disposal system.
\end{abstract}

Keywords:Poultry wastage, Environmental pollution, Total Bacterial Count, IMViC, Enteric pathogens, Oppurtunistic pathogens.

\section{Introduction}

Poultry is one of the fastest growing agricultural sectors in India [1]. This leads to significant raise in the production of broilers at the rate of 8 to $10 \%$ per annum [2] with an annual turnover of 30,000 crores [3]. The advantages of low investment and the requirement of small area have increased the number of poultry shops and creating employment opportunities [4]. This also leads to the generation of huge quantities of poultry wastes usually composed of broiler and layers, feathers, bones, blood, hatchery debris and dead birds. These wastes pose serious environmental pollution problems through microbial infection, offensive odours, promotion of flies and rodent breeding [5]. There are no proper disposing units for these wastages in developing countries like India but attempts are in process to reuse these materials as beneficiary ones such as fertilizers and animal feed supplements [6]. As these wastes are composed of tissues and blood, we have hypothesized that these deposited wastes may serve as a reservoir for the multiplication of several pathogenic microorganisms that can cause severe disease outbreaks. Hence, the present study was carried out to identify the potential pathogens that can survive in these poultry wastages which can be hazardous.

\section{Materials And Methods}

Study Area

The poultry waste samples were collected from the poultry waste dumping sites in and around Poonamallee town, a suburban situated in the west side of Chennai, Tamil Nadu state, India. Samples were collected from five different regions namely Iyappanthangal, Kumananchavadi, Senneerkuppam, Chembarambakkam and Kuthambakkam. All the sampling sites were densely dumped with the poultry wastages as shown in fig.1 (Kumananchavadi). 


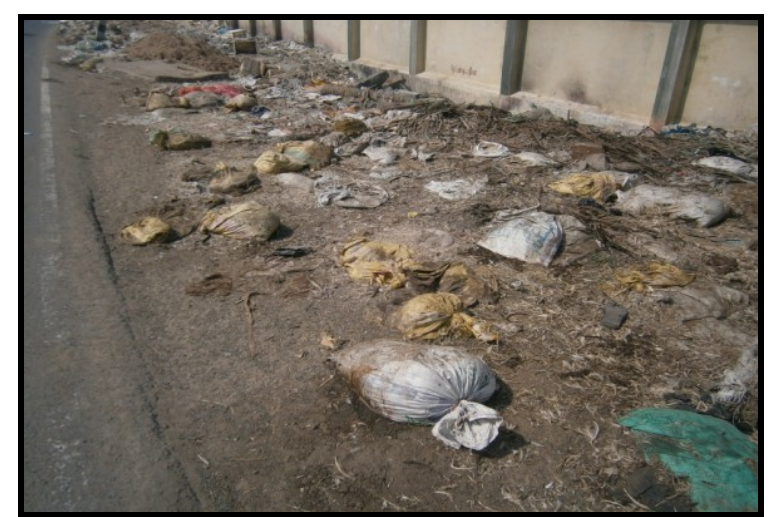

Fig 1. Kumananchavadi Poultry wastage dumping site

\section{Sample Collection}

The samples were collected according standard microbiological procedures $[7,8]$ during pre-summer season in the month of January 2013. In brief, about 2 gram of samples were collected in sterile containers using sterile spatula (as shown in fig.2) and immediately transported to the Microbiology laboratory of Sree Sastha Institute of Engineering and Technology for further analysis.

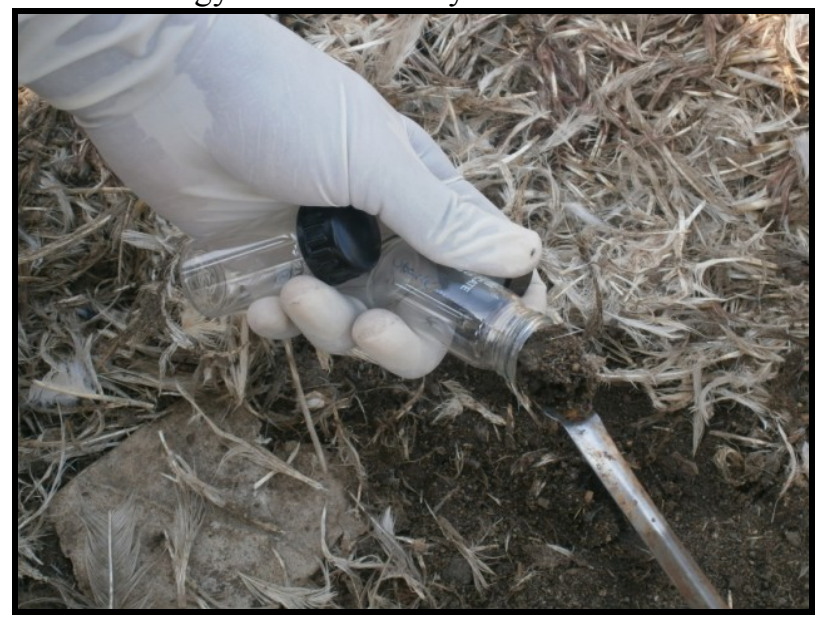

Fig 2. Aseptic collection of poultry wastes

\section{Media and Reagents used}

The media and reagents used for the study such as Nutrient Broth, Nutrient agar, Eosin-MethyleneBlue agar, Blood agar, Salmonella-Shigella agar, Thiosulfate-Citrate-BileSalt-Sucrose agar, Mannitol Salt agar, MacConkey agar, Methyl red and Voges Proskauer were procured from Himedia, India.

\section{Sample Processing}

The collected samples were aseptically processed in the microbiology laboratory. $500 \mathrm{mg}$ of each sample was inoculated into $100 \mathrm{ml}$ of freshly prepared nutrient broth and incubated for 24 hrs at $37^{\circ} \mathrm{C}$. After incubation, the total viable count of the bacteria and screening for the potential pathogens were carried out.

\section{Total Bacterial Count}

The total bacterial count was performed to all the samples by Lazy Susan plating method in triplicate on solid Nutrient agar plates after serial dilution of samples at 1 in 10 concentrations. The seeded plates were sealed and incubated at $37^{\circ} \mathrm{C}$. The colony forming units were counted after 24 hours using colony counter (I.L.E, India) and expressed in CFU/mg.

\section{Isolation of Pathogens}

Isolation and identification of bacterial pathogens were carried out based on their growth pattern and colony characteristics on selective and differential media. In addition, Grams staining, IMViC, Catalase, Oxidase, Urease and motility tests were carried out according to the standard test procedures $[7,8]$ to confirm the findings. 


\section{Results And Discussion}

The total bacterial count was assessed to all the samples and described in fig 3. Bacterial counts are presented as the average of the actual triplicate values. All the study regions have shown significant load of bacteria. Among the five different regions Kumananchavadi has the highest bacterial load with $1088 \times 10^{9}$ $\mathrm{CFU} / \mathrm{mg}$ of sample. This region had a huge dumping of fresh poultry wastages and debris in sacs when compared to other study regions. Moreover this dumping site usually founds with fresh blood and other body fluids that supports the growth and multiplication of most of the pathogenic bacteria [9].

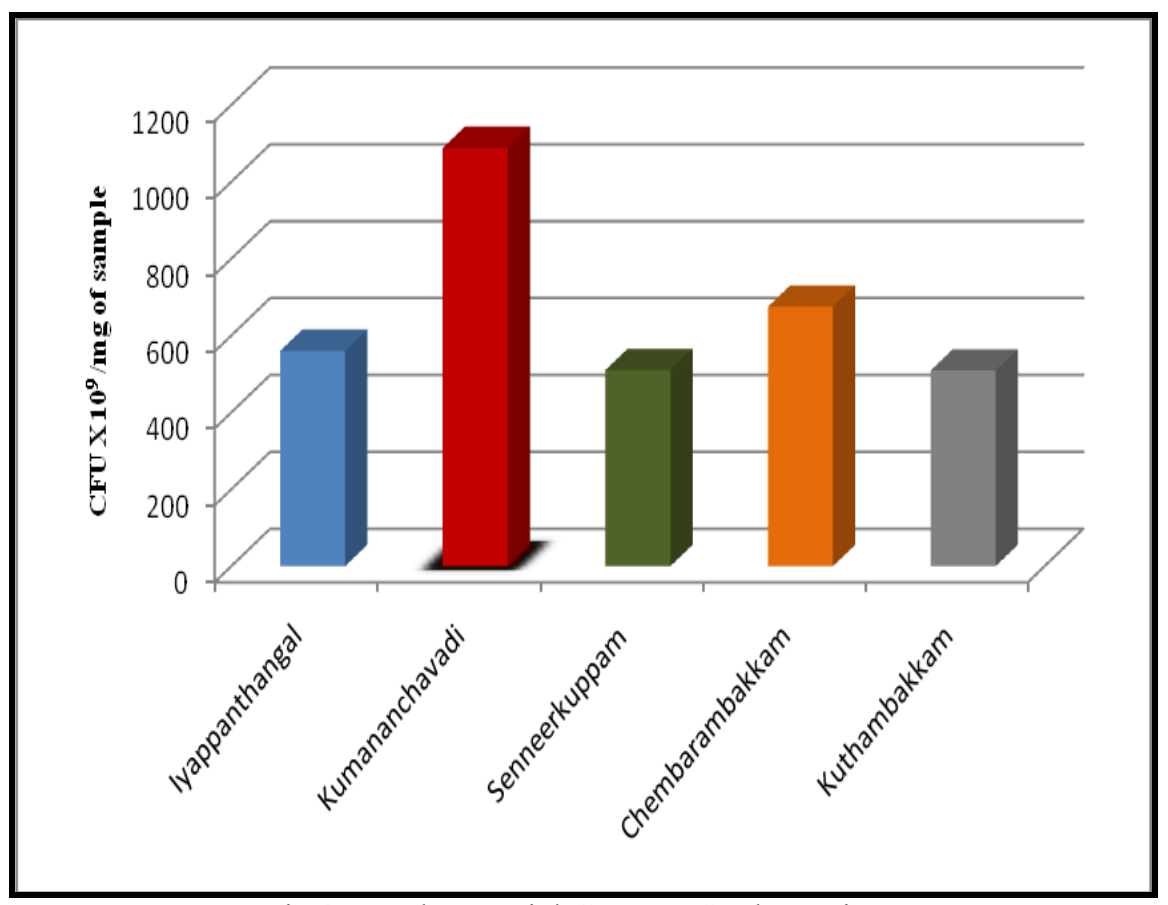

Fig 3. Total Bacterial Count at Study Regions

The pathogenic organisms were identified and confirmed through the standard biochemical tests and the regionwise distribution is given in Table 1. Present study has revealed the presence of potential pathogens such as Vibrio cholerae, Vibrio parahaemolyticus, Salmonella typhi, Klebsiella pneumoniae, Shigella dysenteriae and Shigella sonnei in the study regions. The opportunistic pathogens such as E.coli and Staphylococcus sp. were also isolated. The typical growth characteristics of Salmonella typhi and Vibrio cholerae on SS agar and TCBS agar respectively are given in fig 4 and fig 5 .

Table 1. Distribution of pathogens

\begin{tabular}{|c|c|c|c|}
\hline S. No & Samples Sites & Bacterial pathogens & Opportunistic Bacterial pathogens \\
\hline 1 & Iyappanthangal & $\begin{array}{l}\text { Vibrio choleare } \\
\text { Salmonella typhi } \\
\text { Shigella dysenteriae } \\
\text { Shigella sonnei }\end{array}$ & $\begin{array}{l}\text { E. coli } \\
\text { Staphylococcus sp. }\end{array}$ \\
\hline 2 & Kumananchavadi & $\begin{array}{l}\text { Vibrio choleare } \\
\text { Vibrio parahaemolyticus } \\
\text { Salmonella typhi } \\
\text { Shigella dysenteriae } \\
\text { Shigella sonnei }\end{array}$ & $\begin{array}{l}\text { E. coli } \\
\text { Staphylococcus sp. }\end{array}$ \\
\hline 3 & Senneerkuppam & $\begin{array}{l}\text { Klebsiella pneumoniae } \\
\text { Salmonella typhi } \\
\text { Shigella dysenteriae } \\
\text { Shigella sonnei } \\
\text { Vibrio parahaemolyticus }\end{array}$ & $\begin{array}{l}\text { E. coli } \\
\text { Staphylococcus sp. }\end{array}$ \\
\hline 4 & Chembarambakkam & $\begin{array}{l}\text { Klebsiella pneumoniae } \\
\text { Salmonella typhi } \\
\text { Shigella sonnei }\end{array}$ & $\begin{array}{l}\text { E. coli } \\
\text { Staphylococcus sp. }\end{array}$ \\
\hline 5 & Kuthambakkam & $\begin{array}{l}\text { Salmonella typhi } \\
\text { Shigella sonnei }\end{array}$ & $\begin{array}{l}\text { E. coli } \\
\text { Staphylococcus sp. }\end{array}$ \\
\hline
\end{tabular}




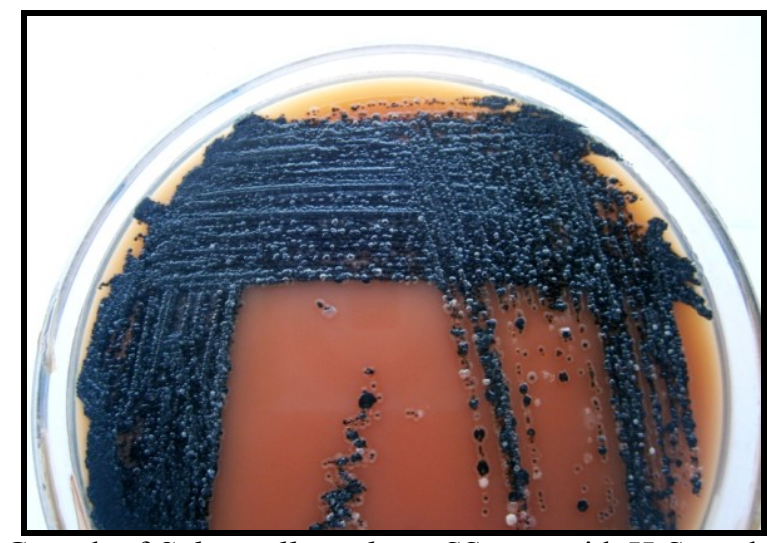

Fig.4 Growth of Salmonella typhi on SS agar with $\mathrm{H}_{2} \mathrm{~S}$ production

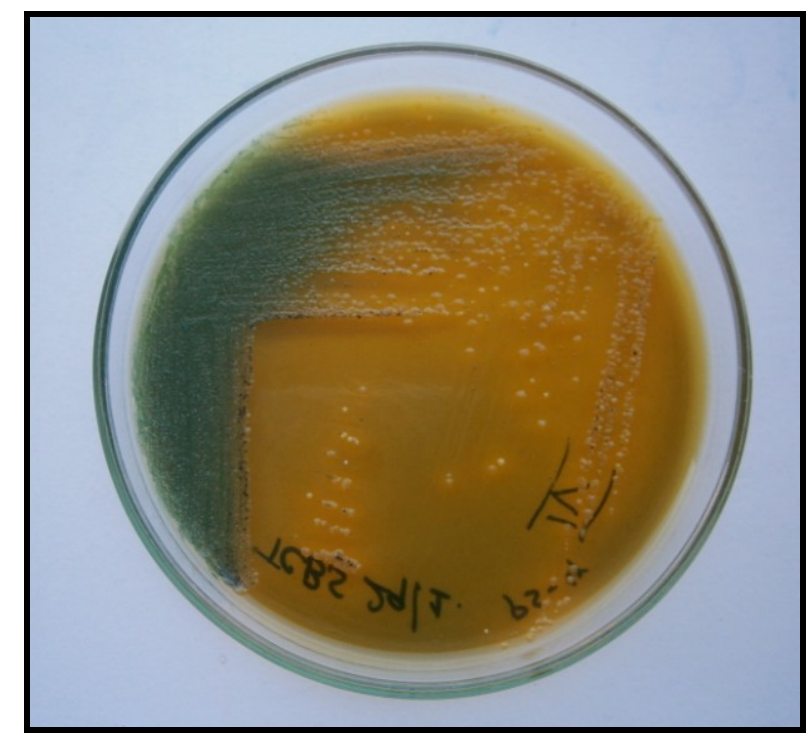

Fig.5 Growth of Vibrio cholerae (Golden yellow coloured) on TCBS agar

India is the ninth largest broiler producer in the world today [10]. The production and processing of poultry involve killing, defeathering, eviscerating and cleaning that lead to the generation of wastes. Coker et al [9] showed that these wastes can affect water, land and air qualities if proper practices of management are not followed. Hence it is important to study the prevalence and distribution of different bacteria in these poultry wastes.

The findings of the present study support the study hypothesis that the deposited poultry wastes serve as a reservoir for the growth and multiplication of bacteria. All the samples have showed significant bacterial growth. The isolated organism Vibrio cholerae is the causative agent of cholera that spreads through the contaminated water. Epidemic outbreaks are more common as it spreads through convalescent carriers and the incubation period for these bacteria is of 1-5 days [11]. Another species V. parahaemolyticus is capable of causing gastroenteritis through contaminated water and food. Presence of these organisms is a big threat to the community living in these regions.

The samples also revealed the presence of Shigella dysenteriae and Salmonella typhi which are also serious enteric pathogens. Shigella dysenteriae can cause severe dysentery and prostration to the infected people [12]. The major threats with this organism are; it remains viable in moist environment for several days and a small infective dose such as 20-100 bacilli is enough to cause the infection. Salmonella typhi is the causative agent of typhoid fever in which the organism invades the intestinal mucosa and multiplies there. Occasionally they manage to enter the lymphatic and cardio vascular systems to cause serious illness [13]. Presence of other bacteria such as K. pneumoniae, E. coli and S. aureus is also a major environmental health problem. They can cause urinary tract infections, respiratory tract infections and gastrointestinal tract infections [14].

The colonization of pathogenic bacteria in these dumping sites is highly hazardous to the environment. If these infectious poultry wastes are discharged into lakes, ponds and/or other drinking water resources it can harm aquatic life and jeopardise the quality of our drinking water [15]. In addition, the nuisance odour arises 
from these materials has also an impact on greenhouse gas emissions associated with global climate change [16]. These waste materials need prompt disposal system or should be utilized as an alternative source. Several ways of disposing methods are followed worldwide such as burial, rendering, incineration, composting, feed for livestock, fertilizer or source of energy [6] as recommended by Hazard Analysis Critical Control Point (HACCP) guidelines [17] and Environmental, Health, and Safety Guidelines for Poultry Production Guidelines [18]. Poultry waste materials also contain organic matter that can be converted into bioenergy under anaerobic conditions which yields biogas, a gas mixture with varying concentrations of combustible methane [19]. But, before proceeding with these processes an effective screening procedures like the present study are important.

Present study has some limitations. It has focussed to screen only the aerobic bacteria and not other microorganisms such as anaerobes and fungus. The reason is the limited availability of resources and laboratory facilities. Special infrastructure and culture conditions are required to screen for more number of other pathogens. Investigations with advanced techniques like PCR, molecular sequencing and flow cytometry may reveal more scientific information.

\section{Acknowledgment}

The authors thank the Management, Principal and Faculty members of Sree Sastha Institute of Engineering and Technology, Chembarambakkam, Chennai-600123, for their constant encouragement and support throughout this work.

[1] www.apeda.gov.in (Accessed on $14^{\text {th }}$ October 2013).

[2] http://www.icra.in (Accessed on $15^{\text {th }}$ October 2013).

[3] Mehta R, Nambiar RG, The poultry industry in India. www.fao.org/ag/againfo/home/events/bangkok2007/docs, 2007.

[4] Agblevor FA, Beis S, Kim SS, Tarrant R, Mante NO, Biocrude oils from the fast pyrolysis of poultry litter and hardwood Waste Management and Research, 12, 2010 2165-2172.

[5] Adeoye GO, Sridhar MKC and Mohammed OE, Poultry waste management for crop production: Nigerian experience. Waste Management and Research, 12, 1994, 2165-2172.

[6] Kelleher BP, Leahy JJ, Henihan AM, Dwyer TF, Sutton D, Leahy MJ, Advances in poultry litter disposal technology - a review. Elsevier 83, 2002, 27-36.

[7] Microbiology: A Laboratory Manual (9th Edition) By James Cappuccino, Natalie Sherman.

[8] Steubing, P. M. 1993. Isolation of an unknown bacterium from soil, 14, 1993, 81-114.

[9] Coker AO, Olugasa BO, Adeyemi AO, Abattoir waste water quality in Southwestern Nigeria. Proceedings of the 27th WEDC conference, Lusaka, Zambia, Loughborough University press, United Kingdom. 2001, 329-331.

[10] http://www.niir.org/profiles/profiles/meat-chicken-egg-pork-fish-processing/z,,32,0,a/index.html (Accessed on $15^{\text {th }}$ October 2013 ).

[11] Ananthanarayan R, Paniker CKJ, Textbook of Microbiology $8^{\text {th }}$ edition (309), 2009.

[12] Willey JM, Sherwood LM, Woolverton CJ, Prescott, Harley, and Klein's Microbiology $7^{\text {th }}$ edition, 2008.

[13] Bhunia R, Hutin Y, Ramakrishnan R, Pal N, Sen T and Murhekar M, A typhoid fever outbreak in a slum of South Dumdum municipality, West Bengal, India, 2007: evidence for foodborne and waterborne transmission. BMC Public Health, $27,2009$.

[14] Jann-Yuan Wang, Po-Ren Hsueh, Jann-Tay Wang, Li-Na Lee, Pan-Chyr Yang, Kwen-Tay Luh, Infections and Chronic Colonization by an Escherichia coli Clone in the Respiratory Tract of a Patient with Severe Cystic Bronchiectasis, Journal of Clinical Microbiology, 38, 2000, 2766-2767.

[15] www.arc.govt.nz (Accessed on $15^{\text {th }}$ October 2013).

[16] Williams CM, Poultry waste management in developing countries, North Carolina State University, Department of Poultry Science, Raleigh NC, United States of America.

[17] Pope MJ, Cherry TE, An Evaluation of the Presence of Pathogens on Broilers Raised on Poultry Litter Treatment-Treated Litter. Poultry Science 79,2000,1351-1355.

[18] World Bank Group, Environmental, health, and safety guidelines: Poultry processing.(Advances in poultry litter), 2007.

[19] FAO /CMS, Biogas technology: a training manual for extension, 1996. 